\title{
The Bicycle for War Purposes
}

\section{Captain B. F. S. Baden-Powell}

To cite this article: Captain B. F. S. Baden-Powell (1899) The Bicycle for War Purposes, Royal United Services Institution. Journal, 43:257, 715-736, DOI: 10.1080/03071849909423615

To link to this article: http://dx.doi.org/10.1080/03071849909423615

$$
\text { 曲 Published online: } 11 \text { Sep } 2009 .
$$

Submit your article to this journal $\pi$

山ll Article views: 6

Q View related articles $\longleftarrow$ 


\section{THE JOQRNAL}

\section{ROYAL UNTED SBATH INSTITUTION.}

VoL. XLIII. JULY, 1899. No. 257.

[Authors alone are responsible for the contents of their respective Papers.]

\section{THE BICYCLE FOR IVAR PURPOSES.}

Bj" Captain. B. F. S. BADEN-POW ELL, Scots Guards.

Wedncsday, March 15th, 1890.

Iajor-General II. H. D. SrRACEY in the Chair.

PART I.

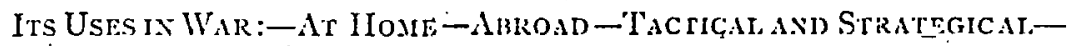
As a Meavs of Transtorting 'Troops-Scouting-OrderlaAs Mocmted INfaxtri-Thassport-Conterance of Wouxded -Special-Ro.ins.

'TO begin with, I think it would be superfluous on my part to dilate on the advantages of the employment of bicjcles in war. They may be briefly summarised by saying that such machines enable the soldier to be rapidly transported from place to place at a speed about three times greater than the ordinary marching and without uilising the expensive, forage-consuming, noisy, and comparatively delicate horse. The subject has been exhaustively treated of by Colonel Savile (in a lecture before this Institution in 1888) and by Colonel I3alfour (in a chapter on "Employment of Cyclist Infantry" in Gall's "Tactics").

But since these articles were written great changes have been made in the construction of cycles, and the whole subject lias been more carefully considered. Thanks to our Voluntecrs, much practical experience has been gained, and it now seems probable that we shall shortly'actually introduce the bicjcle as a regular and recognised addition to a modern Army. As regards foreign Armies, an excellent account of, what has been done has been compiled by Licutenant Whitney, of the U.S. Army; in the Journal of the Militay Service Institution. At home we are about to take a definite step in this matter by the systematic training at Aldershot of sections of Regular troops. One subaltern, one sergeant, one corporal, and twenty-five men from each battalion will be taken in turns and trained under the supervision of Colonel Alderson, the oflicer commanding the mounted infantry. Altogether five companies are to be trained, the voL. XLIII. 
course lastia; six weeks. Just at present, too, the cycle construction scems to be narrowing down to one groove. Only a few years ago there were many different patterns of machine, bat now that we have had experience of them all it seems that the time has come to decide on the exact pattern of machine most suitable for military purposes.

Considering the popularity of cycling, it seems curious that more has not recently been written on the subject of its adaptation for war, and as no one else more competent than myself seems inclined to bring it forward I have collected the notes for the following paper in hopes they may be of use and interest.

I had intended to confine my remarks to the details of construction only; but before that can be gone into at length it will be necessary to consider what qualities are required, that is to say, in what manner a machine is most likely to be used in war.

Now there are three principal circumstances under which British Ir ups may be employed on service, each of which would secm to require a somewhat different type of machine:--

1. At home, in case of inzasion.-Here, where roads are comparatively plentiful and good, and supplies usuaily obtainable in the thickly populated districts, the great object of the cyclist would probably be to dash about the country in the lightest order. A light machine might then do, as cven repairing and replacing will not be so great a difficulty.

2. Abroad, where the roads are good and plentiful, yet where it may be necessary to carry provisions and supplies to last several days. 'This would involve more of a weight carrier and a stronger build.

3. Abroad, where the roads are comparatively feav and bad.--There the whole action of cyclists would be much curtailed. Speed wopuld probably have to be sacrificed to solidity. A specially strong machine would be necessary to stand the rough work, but it would be more unlikely that the cyclists would be despatched far distant from the main force, so that they would seldom have to carry supplies.

It is in the first of these categories, for home defence, that the cyclist would probably prove of the greatest value. Not only are the roads good and plentiful and well known, but our organisation for home defence is notably deficient in cavalry. But in an enclosed country like Fngland the action of cavalry would be very greatly confined to scouting along roads, and for this particular purpose cyclists are undoubtedly sunerior to horsemen.

But to properiy investigaie the stitability of various types of machines we must further sub-divide the subject, and I suggest the following various ways in which cyclists may be employed :-

1. Strategical, i.e., as a method of conveying rapidly comparatively large bodies of troops to the seat of war. They may thus rapidly concentrate on any point independent of railways, the machines being solely for use in the stratesical sense for conveying troops to their destination, where the machines could be left stored, and the force act as ordinary-infantry. Suppose, for instance, news was suddenly received that an invading force were threatening to land on our coasts-anywhere between the Thames and 
the Isle of Wight, a battalion mounted on cycles could be despatched from London, and within 5 or 6 hours be on the scene, without waiting for trains to be prepared or other arrangements made, and leaving the railway quite free for the transport of stores and supplies, and other troops. Not only one battalion, but a dozen could be sent, utilising different by-roads which would have been well surveyed and considered beforchand.

This should be a mos/ important factor in home defence. It might even be possible to have the greater part of the Volunteer Force so organised, since nowadays most men ride and possess bicycles, and occasional practice rides would be sufficient training. Troops could thus be brought to the theatre of war from all parts of the country by stages, marching their 40 or 50 miles a day.

And this, of course, not only applies to home defence in England, but, in many cases, to the defence of our great Colonies, and especially to operations in India.

It may be objected that such large bodics would involve enormously long columns. So they may; but, after all, they would not be so long as columns of cavalry

Incidentally, while speaking of Volunteers as cyclists, I hear it said that many of our young men, and those most suited for Voluntecrs, prefer soing for their bike ride on a Saturday afternoon to doing a bit of steady drill in the barrack squarc. The extension of Volunteer cyclists then might be a great incentive to Voluntecring, and properly organised military tours would doubtless prove popular.

For this particular mode of employment, Volunteers would of course have to use their own machines, and no one special pattern could well be adopted. But for Regular troops it might be desirable to have stores of bicycles ready. Such machines, merely to be used as a mode of locomotion, enforce no very definite qualifications. They would be primarily for use on fairly good roads, not required for long or severe use, and need not be arranged for many of the purposes to which I shall presently refer. Clieapness, and compactness for storage, would then be the most sought-for qualities. It may also bo desirable that such a machine should be a good baggage carrier, so that kits and provisions, and a good supply of ammunition could be carried. On the other hand, under such circumstances, stores of all kinds might be rapidly sent to the front by the otherwise unencumbered railways.

But such a mode of marching is applicable also to other forms of warfare than the defence of our shores. One is often apt to look upon war as a series of battles, and to forget that for every dlay of fighting there are perhaps twenty or thirly spent in marching quietly along the roads from place to place. Wherever roads are good and plentiful, large bodies of infantry on cycles could be beneficially employed. And indeed there are many countries where roads for wheeled traffic arc unknown, yet where the native tracks are eminently suitable for cycling.

2. Raiding. The next use of cyclists which we will consider is what may be included under the head of raiding. I am not exactly refurring to that species of warfare as exemplified by certain recent 
operations under Dr. Jameson, but I mean a rapid march into the enemy's country for some particular object, such for instance as the destruction of a railway bridge, the cutting of communications, or even the relief of a more or less hemmed-in force. In these cases, celerity is all-important, yet hard fighting may be expected at any moment.

For such a purpose, given good roads, cycles would be of the greatest use, since distances could be covered in a short time by this means, such as would be impossible even to horses. But it demands a really good machine. Every little breakdown would be fatal. Qualities for speed, weight-carrying, and strength are essential.

3. Scouting and Reconnaissance.-For these purposes also cyclists will be most valuable, especially when there is a deficiency of cavalry. As a rule, patrols would be sent out from camp to go a certain distance and return, so that but little weight need be carried on the machines, beyond the rifle and a small supply of ammunition. This may be either for watching the enemy or only for surveying the country. It would be especially useful for outposts.

Under this heading may also be included the advance and rear guards of a force on the march, for which cyclists are eminently suitable, being able to kecp a long distance ahead of the force (or behind in retreating), yet able to rapidly send back word when the enemy is met or obstruction is to be cleared.

4. As Mounted Infantry to a force of all arms.-It has often been said that mounted infantry must not ape cavalry, and authorities on military cycling have gencrally decided that this is still more the case with cyclists, who, they say, possess no shock action. And, though this may generally be the case, still, given favourable open ground-such as smooth level grass-a force of cyclists, especially if they be armed with revolvers, might well ride rapidly down upon a force of broken and demoralised infantry, and on getting to close quarters drop their machines and charge home. . Under this heading rould of course be included their employment as escorts or conioy's to cavalry, guns, or rapidly moving columns of supply. They would be most useful with the cavalry screen, supplying not only a readily available force of infantry, but save much time and work in keeping up communication with the main forces.

Great speed would not usually be called for, but the force must always be prepared to be away for some days and so carry supplies with them.

5. As Orderlies and Messengers. - This is the purpose to which cyclists have hitherto been most practically put. As such, the man would usually carry no impedimenta. He might even as a rule go unarmed. Rapidity is important here, and a very light machine would suffice. It is not only in and about camp that such would be most useful, but also, in a lesser sense perhaps, owing to the difficulties of cross-country . riding, for carrying despatches and messages in the field.

6. For Transport.-Now here is a subject which does not seem to have been sufficiently considered. Given a thoroughly strong machine 
and fair roads, the transport of supplies might be carried out on emergency by cyclists in a surprising manner.

Setting aside the possibility of utilising such machines as "carriers" or others specially made for transport, I will only refer to the ordinary bicycle, which I believe could on emergency form a novel and rather remarkable means of transport. Thus, for: -1 . Collecting supplies from the country round: a most important duty when a large force remains stationary for some time. 2. Rapidly bringing up supplies of ammunition, intrenching tools, etc. 3. Bringing up supplies from the rear to a force moving forward without sufficient transport. 4. For a lightly equipped flying column.

Now, under such circumstances (except the last) we will presume that the force is encamped and not in danger of immediate attack from the enemy: The cyclists would leave most of their kit, arms, and ammunition behind with the force, and proceed at a rapid speed to the locality where they are to obtain their loads. It may be objected that a cycle can carry no great weight beyond its rider, but speaking from experience I know that an ordinary cyclist can carry at least $200 \mathrm{lbs}$. on his machine in addition to himself. This may sound a lot, of course, but we know how a bicycle will bear the weight of three men, one on the handle-bar and one on the step behind. It may not be desirable to constantly impose such a burden on a machine and bump it along bad roads; but I am now only referring to emergencies; moreover, it would not be desirable to maintain any very rapid pace, and on hills and bad bits of road it may be necessary to dismount. Still, it would probably be quite practicable to maintain a speed of say 5 or 6 miles an hour over a good many miles of average road, carrying at all events a hundredweight. And now look at what this implies. A G.S. wagon with four horses takes a load of 30 cwt., that is as much as thirty cyclists. A horse requires about ten times the weight of food that a man does, and is of no use except for transport, and requires men not only as drivers but also as escort. Therefore the four horses consume as much food as forty men. The wagon wears out the roads and is liable to block them if a breakdown occurs, and cyclists would make two or three journeys to and fro over the same road bringing up supplies in the same time that the wagons made one.

Under this head we may include the conveyance of wounded in an emergency. We have seen at the Military 'Tournament how a man can be carried on a stretcher between two bicycles, even if the poor patient did prefer to be left to die in peace rather than be conveyed by this precarious method.

7. Special Purposes. - There are certain other purposes to which bicycles may be applicd. 'Thus, signallers, who now, when on the march, have to stand and despatch their messages and then run after their battalion to catch it up, would find bicycles most convenient. Military telegraphists have used cycles in America with most satisfactory results for carrying men to repair their wires. 
For topegraphers bicycles are of course most useful. In marching with a colimn, frequent halts can be made to fill in the sketch or report, and the column rapidly caught up again. Side roads can also be examined; while the machine itself forms a most useful instrument, as a cyclometer, clinometer, plane-table, etc., can be attached to the machine. Cooks and men to collect fucl, etc., being mounted could remain behind and clear up and leave camp long after the column had started, and passing it, may arrive at the new camping ground to get well prepared before the arrival of the force.

Having thus considered the different objects for which a cycle is suitable, we must briefly consider, before discussing the details of the machines, the ground over which we may want to operate.

Rouds.-Of course, everything, from the cyclist's point of view, depends on roads, but there is one point to remember. As regards the use of cyclists over the line of communication, whether for orderly work, conveyance of troops, transport, etc., when the same road will be perpetually used, it would be comparatively easy to keep a track in good repair. In wild countries it would be much easier to make a narrow cycle track than to build a regular wide cart road. Such tracks could be rapidly cut through forests or over rocky mountains. Fven a boarded track would not be difficult to lay in many places, such as over marshy ground. There is a vast difference between making a smooth track a foot or two wide, and a roadway to stand heavy traffic, say, 20 fect wide.

lracks used by bare-footed natives are generally suitable for cyclesso long as the gradients are not too great, or roots numerous. The sharp stones and thorns that would puncture a pneumatic tyre would also puncture a native's foot, and would therefore not exist in much-frequented paths.

In snow too, so unfavourable as a rule for cycle riding, hard tracks can soon be formed.

But cyclists are not necessarily entirely confined to roads. Large tracts of open plains are frequently met with over which cycles could travel in any direction, and though perlaps such cross-country riding may not be rapid or pleasant for ordinary touring, yet with proper training military cyclists should be able to do a lot of cross-country work.

PART II.

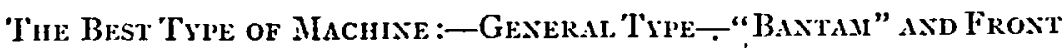
Drivers - Folding - Tripartite - Tandeis - MuthicyciesDetalls of Constructos-Trres-Chais and Gears-Med

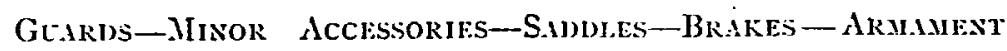
and EQuipheat-Arms-Machine Guns-Kit Required.

Wre will now consider the most suitable type of machine for general service.

The usual build of safety bicycles of to-day-and there is no very great variety-is the outcome of years of practical experience. It is the survival 
of the fittest of a vast number of patterns and a multitude of eccentricities. We should therefore take this as our groundwork. There are, however, a few qualities which a military machine calls for, which are not of importance in the ordinary machine, and which, it will therefore be necessary to add.

The first consideration of a military machine is that it must be thoroughly strong. A light machine cannot be expected $t$, ) stand the roughing of a campaign. It is probable that this will necessarily involve aveight, and it will not probably be possible to make it much lighter than 40 Ibs. The new French machine (110/ the "Gérard") weighs 45 lbs.

It will of course be necessary that all parts should be interchangeable, so as to facilitate repairing. The parts usually plated should be dulled or blucd so as not to glitter in the sun.

As for material, though stecl is usually considered better than aluminium or bamboo, that great authority, Mr. J. K. Starley, is in favour of a metal that will not deteriorate by oxidation. He suggests aluminium if a method can be found of satisfactorily joining it, and phosphor-bronze for certain parts, such as the spokes.

As regards the gencral form, it would be best to have the two whecls of the same size, so that the tyres, etc., could be interchangeable. .

It is a pity a bicycle does not float in water. Not only in swimming rivers would this be desirable, but the capsizing of a boatful of cycles would now be a serious matter. Its displacement should support about $20 \mathrm{lbs}$., and if all the tubing were bigger, it might be made to float. 'The tubing of a bicycle might easily be arranged to form a reservoir for water. The handle bars alone would hold just a pint, and if detachable, might almost take the place of the water-bottle. Oil, too, not only for lubrication, but for lamps, could be kept in some portion of the tubing.

There is one type of machine, however, still popular in some quarters, which is of different form to the ordinary pattern of safety. I refer to that known as the "Bantam." This possesses one great advantage of being only $4 \frac{1}{2}$ feet long instead of the usual 6 feet. This is not only of value as considerably shortening the length of a column of cyclists, but is also of value in storing the machines, and making the cycle more generally handy. Its weight, too, is less than other machines, it being of more compact build, while its neat gearing I will refer to later. On the other hand, the "Bantam" may not be as good for general ridingr purposes.

But, after all, it is possible to make a machine shorier without necessarily designing it after the model of the "Bantam." With smaller wheels and a shorter frame, a compact and stronger (or lighter) machine may be made. A small wheel is bound to be both lighter and stronger than a larger one in which the same sectional size of spokes, tyre, and rim is used. By making a lower frame, even if not so handy in turning, il will be possible to "toe" the ground and stop without dismounting.

We thein come to a type much advocated in some quarters for war purposes, i.e., the folding machine. 
Colonel Pilleau, R.E., says:- "I think it is now accepted as a fundamental truth that a military cyclist must be mounted on a folding machine."

Captain Gérard, of the French Army, is, I suppose, the originator of such a machinc, and having had a goo.t deal of practical experience with it, pronounces very strongly in its favour. His machine certainly does not appeal to the eye of the practical cyclist. Thic fact of the rider being directly over the hind axle, a special feature of the "Gérard" patent, not only does not look well, but Licut.-Colonel Donglas, R.A..II.C., who has ridden about 1,400 miles on one, tells me he has found frequent trouble with burst tyres and worn-out bearings from this cause. The single tube, too, joining the whecls has a decidedly weak look, although it secms to have stood plenty of rough work abroad. The weight is $32 \mathrm{lb}$., and it takes 40 to 45 seconds to fold or unfold.

All the other folding machines I know of are made with a frame very similar to the usual one, but jointed with hinges in the upper and lower, tubes. In the "Offord" machine these hinges are made in the ordinary frame tubes, and, when set up, a slecve slides over each hinge. In the "Folder" the tubes are prolonged so as to overlap, and a rertical tube strengthens the frame. "The "Belgica," of which a large number has been purchased by the Belgian Government, has a second backbone, all these tubes being hinged in the middle. In the "Alstrom" only handle bars and pedials are folded.

Folding machines secm to be in great favour among the authorities abroad. The report of the Austrian mancurres of 1896 says, "The difficultics of tha ground have, so to speak, disappeared in presence of the ! folding cycle." After the German mancuvres of 1897 it was snid, speaking of the best patiern of war cycle, "It can hardly be doubted that a folding màchine is preferable." Both in Spain and Russia a number of folding machines of the "Gérard" type have been uniler trial. In Italy, too, a cyclist company has been formed, of which half are on folding cycles.

The advantages claimed for a folding cycle are:-

1. That when a piece of rough ground has to be crossed it is desirable to be able to fold the machine and carry it bodily over the ground. This applies to heather and long grass, to rocky country, to marshes, and also to steep hills, up which it becomes very difficult to push a heavily burdened machine. Such advantage is specially noticeable when a cyclist detachment, in skirmishing up a hill, or over rughh country, to clear it of the enemy, leaves the machines at the botton, and then has to return down again to get its machines.

2. Compactness in storage especially for railway and steamer travelling. With the usual form of machine it becones very difficult to stow away any large number without rendering them liable to damage.

Some objections have, however, been urged against such machines It has been said that the occasions are few and far between when th ground is so bad that the machine cannot be wheled, though I thin:. such idcas must be gained from experience during peace-time and mancuvres when cross-country work is usually much restricted. 
Also that on such occasions any machine can be carried on the shoulder, though not comfortably or in such a way that the riffe can be used. It is also urged that a man cannot carry the weight of a full kit and a bicycle as well. But even here it nust be remembered that he only carries the bicycle for a comparatively short distance, and that on many occasions he would be in light order, having left his kit in camp. Again, it is urged that a considerable time would ușually be wasted in strapping the machine on the man's back and undoing it again. So, far, however, these my be considered as negative objections, in that they point to a foldling machine not being a necessity rather than to its being objectionable. The actual objections are tliat the makes of folding bicycle referred to are necessarily more or less heavy and complicated. If made light they must be weaker than an ordinary machine, and though a pound or two extra weight may not be of extreme importance, they all have several bolts and hinges and other complications which may get out of order, especially after weeks and months of jolting and rough wear, in getting sand and grit in and receiving bumps and knocks. Simplicity of construction is undoubtedly of great importance.

With these conditions before me I have sought to devise a machine which should be foldable and yet at the same time no heavier or no weaker than an ordinary machine and free from complications. I hit off the idea you see exemplified here, called the "Tripartite" (Plate 8, Fig S. 1, 2, 3) fitting. The machine is defachable rather than foldable. There is a sleeve in the head which retains in place the balls of the upper and lower bearings, and a wing-nut secures the head clamp which, on being loosened, allows of the handle bars and the steering post being withdrawn from the head. The machine is thus easily divisible into three separate parts, which may then be hooked togethrr, when it occupics a space very little greater than the most compact fola.ag machinc. Indeed it possesses an advantage over a hinged folding machine in that the pieces can be arranged fatler. I have often taken this machine with me in a railway carriage and stowed it underneath the seat, which would be impossible with other folders."

In this type the ordinary machine is taken (this one is a "Premier"), with its well-tried diamond frame intact, nothing is detracted from it, and only a very simple portion added, which does not add $\$ \mathrm{lb}$. to the weight. 'The' frame is in no way weakened, and very' little complicated-indeed, in some ways it may be said to simplify the ordinary arrangement, as should anything go wrong in the head, it is so much easier to take to pieces. It also has the great advantage of being adaptable to any existing machine and at a cost of only a few shillings, and may thus be suitable for Volunteers.

The operation of folding only takes about 10 seconds, and it can then be readily slung over the shoulder without necessitating any adjustment of straps. A man can thus jump off the machinc, fold it, have it slung, and be on the march within 15 seconds. He might have crossed

${ }^{1}$ Many of the principal makers, such as the Premier, Rover, Rudge-Whitworth, Marriod, and others, are now applying this invention to their machines. 
60 yards of the bad ground before a man with a "Gérard" would have had his machine properly fixed on his back. This method of slinging a heavy machine also enables a man to readily rest the weight of it on the ground at any moment, as for instance when he kncels to firt. But on the other hand, if it should be any advantage to have the machine properly fixed on the back, it can of course be done quite easily with this pattern. Norcover, if it should be considered desirable for the man to have his kit on his back there is no room for a bicycle; but with the "Tripartite" arrangement he can hook it over one shoulder.

There are certain additional advantages in a scparable machinc. Thus (presuming they were ail of one pattern), if three machines became damaged from bullets or other causes; each in a different portion, within a few seconds they could be taken to pieces, and two complete machines be built up. This might be of the greatest importance in action. Then again it would often be of advantage in lifting over walls. etc., to have the weight of a machine divided into three packages. And such an arrangement lends itself to various other devices, such as forming the framework of a pontoon boat or the support to a shelter tent. I will leave it to others more competent than myself to dilate during the discussion on the objections to this form of machine.

There is one other kind of cycle that I must refer to. Tandems and Mullicycles have been tried for military work, and possess the advantages, as compared to a single machine, of being:-1. Lighter in weight per man carried. 2. Slightly quicker. 3. 'Take up less room in column of route.

They may also prove of use for carrying machine guns, tools, telegraph poles, etc.

On the other hand, the single machine is much handier and easy to stow, and if it breaks down only one man is dismounted, who may get a lift on another machine.

There are however many circumstances under which it might be most desirable for a machine to carry two men, such as the instance just mentioned, or eren when a small party of ordinary infantry could be carricd by cyclists and rapidly pushed forward or brought back in retreat. At a pinch a man can always be carried sitting on the handle bars. I have myself been thus taken on an ordinary machine for a mile and a half over a hilly and by no means good road. Mr. Starley suggests a couple of folding steps being attached to the hind axle, on which a man could stand.

As regards other qualities desirable in a military bicycle, I think the first consideration should always be simplicily. This would generally imply reduced weight, easier to clean, not so liable to damage or to get out of order. Therefore I should do away, as far as possible, with all accessories such as mud-guards, gear cases, foot rests, etc.

Tyres.-As boots have been said to be the most important part of a soldier's equipment, so we may' speak of the tyre as regards a military cycle. But if $I$ were to attempt to describe and discuss the relative merits of all the tyres on the market, I am afraid I should have to keep you here 
till to-morrow; and as there may be some here who are interested in one or another, I don't know how long the discussion might go on. But I will say one thing. Notwithstanding what advertisements may. say, I believe that all pneumatic tyres are not only liable to puncture. but also to a certain amount of leakage. 'The soldier on service cannot always be dependent on his pump ; and, be it remembered, it is not only through accident as with the usual rider, that punctures will ozcur. On service, were pneumatics used, the encmy would without doubt try various means to wound so vulnerable a point, by scattering on the roads not only tacks, broken glass, etc., but even specially const ructed obstacles of the nature of "crow's feet." It seems, then, an important matter for consideration whether solid or cushion tyres inust not be adopted, notwithstanding their lack of speed and discomfort; and, after all, the old records show that solid-tyred machines were capable of making very fair speeds, the 50-mile record having been accomplished at a rate of no less than 19 miles an hour. There are also several new kinds of solid tyre which may be great improvements on the old. Among them are the "Idris," which has received great praise from some who have tried it.

In the French "Gérard" machines, Michelin's cellular pneumatic tyre is used, which has, I believe, two air tubes, so that when one becomes punctured the other can be blown out.

IHud guards are an addition which I think quite superfluous. They are all very well at home when it is important to keep the uniforms clean, but on service to have to carry about an extra weight of 2 lbs., with considerable complication, and great addition to the difficulty of cleaning, is of course absurd. A bullet striking a metal mud-guard, a collision, or any other slight mishap, may knock the thing sideways, or gouge a jagged splinter from it sufficient to prevent the wheel rotating freely just at a. critical moment. If the machine is fitted with a valise behind the saddle, this would form quite sufficient protection from mud, and in peace-time a light canvas arrangement can easily be applied. 'I'here is only one point where a mud-guard is really required, and yet, I don't know why, it is seldom, if ever, applied there. I refer to a machine without a gear case. The mud from the back wheel continually spatters right into the chain with palpably detrimental results, yet a very small shicld applied in the right place would prevent this.

Chains and Gars.-Chains, however efficient from the theorctical point, are a great source of trouble. Gear cases are objectionable for reasons already mentioned, and also prevent the chain being looked to quickly if anything does go wrong. Without the cases, however, chains are apt to get clogged with mud or dust, and are then apt to get tight and even break. Chains are difficult to clean and keep in good order.

A simple band or ribbon of steel, etc., overcomes some of the above objections; but though often tried, none seems to have proved a success on cycles.

As regards Chainliss gears, there are scveral going which appear to answer satisfactorily. 
1. The Cryplo gear, in which the pedal cranks arc on the axle of the wheel. This is a simple and efficient gear, but is of course only applicable to a front driver, such as the "Bantam."

2. The Acatene, or bevel wheel, seems to have stood the practical test of many years' wear. It has the great advantage of being compact and well protected, both from dirt and damage.

3. Lloyd's Cross-roller possesses the same qualities, and has also given much satisfaction.

4. The Cam gear, on the other hand, is not so compact and neatlooking as the former, indeed, has fow advantages over the chain.

Saddles.-I never could find any two people agree as to the best form of saddle. I believe all kinds can be got accustomed to after a few rides, but that all are equally uncomfortable after three or four hours' steady riding. One would become tired of sitting in one fixed position in the softest arm-chair after that time.

Brak's exist in very many forms. Here again simplicity and strength are important, and it has to be remembered that a heavily cncumbered military machine requires a powerful brake on an unknown declivity, and that back pedalling under the circumstances is somewhat irksome.

Gear Cases have already bcen referred to. If really considered necessary, the simplest form should be adopted and metal avoided, since it is more liable to suffer from knocks and dents and bullet wounds. It is essential that it should be easily detachable.

Lamps.-There is a question as to the extent to which lamps will be required. Under the various headings I have put down they would hardly be required, except for night marches, which would seldom be made except for the purpose of secretly approaching the enemy, when all lights should be prohibited, and for orderly work, when they might be desirable, but this would only apply to a comparatively few machines. Otherwise the lamps would only add to complication, require frequent replenishing and would generally be uscless and in the way. It would probably be preferable when required, to affix them to the machine very low (on axle of front wheel), so as not to be seen so easily from a distance.

Luggage Carriers fixed on the handle bars or head or behind the saddle would be necessary, not only for carrying kits, but also other articles.

Rifle Clips.-It is of course of the greatest importance to ve able to very quickly detach the rifle for use. There are several different methods which have been tried. A very neat clip for holding the rifle has recently been brought out. The rifle is placed between the jaws of the clip (which is merely fixed to the frame) in an upright position, and then turning the rifle so as to lay horizontally the jaw's automatically close and grip the rifle firmly. I also show a still simpler clip.

A support to keep the bicycle upright would be a convenience under many circumstances; so long as it was simple and light. 
A'coupling to connect two bicycles together has been invented by Lord Dundonald, and should prove most useful for all transport work."

A cyclometer of simple form, such as the Veeder, does not add much to the weight or complication, yet would be most useful for purposes of reconnaissance. Possibly officers only need carry them, but it would be preferable for all reconnoitrers to have them so that they would be absolutely accurate in their reports. Thus a scout coming back to report might say he came across the outposts about two miles along the road ; but such a distance is difficult to judge, and his report might be of much greater value if he could say it was exactly one mile and threequarters off. Of course, distances can be measired by counting the revolutions of the pedal, but the cyclometer would be more efficient.

A itatch is another instrument which would be most useful to a cyclist scout, especially if he had no cyclometer.

It may be as well for me to add a word or two with regard to the armament and equipment of the cyclist.

Arms.-There are many good authorities who consider the long rifle an indispensable weapon for the efficient infantryman, but there are also some who are not so enthusiastic about it. Thus Colonel Lockyer, R.A., Chief Inspector of Small-Arms, speaking in this Institution last year, of a universal pattern of firearm for all services, said, "The weapon I am strongly in favour of is a carbine," and then proceeded to point out that as compared to the long rife the present pattern of carbine gives only slightly less muzzle velocity, about the same accuracy, even at long ranges $(1,400$ yards), weighs nearly 2 lbs. less, is 8 inches shorter, and therefore more handy, and is easier to clean. It takes the same ammunition as the rifle. I cannot therefore see where the advantage of the extra weight and length comes in.

The French cyclists are armed with the cavalry carbine. So are the Italians.

But for light scouting service, as well as for orderly work, a long-range rifle is perhaps unnecessary. The scout is to sec, and not to fight, but he requires a firearm for two purposes:-1. Tö make a feint and cause alarm, then accuracy of fire is of little importance. 2. To protect himself if suddenly waylaid or attacked by a small party of the enemy. For both these purposes a pistol is as good as anything, indeed for the latter it is the only weapon. A cjclist going along a road and finding his way barred by two or three of the enemy would be at their mercy had he nothing to rely on but a rifle, which he would have to dismount to use, but with a handy revolver or other pistol he can keep going straight ahead and pot his opponents at close quarters. A few cyclists might even, under favourable circumstances, make a regular charge. A Mauser magazine pistol or, better, carbine might come in well here, although, as pointed out by the above-mentioned authority, it is somewhat complicated and has too light a bullet to have much stopping power. I find it, however, very easy to take to pieces, so that any part could be rapidly replaced. $\lambda$ for range the service Webley ( 44 bore) has actually sent a heavier 
bullet to the extraordinary distance of 1,578 yards! The Austrian cyclists were only armed with the revolver during manouvres. The weapon must be capable of being used with one hand only.

A light machine gun would of course be most useful to a party of cyclists. Mr. Maxim has one now which weighs only 25 ibs., and could easily be carrice on a bicycle if others carricd the ammunition.

As regards officers, there is one weapon which I unhesitatingly should condemn, and that is the sword. If attached to the cycle, and if not a folding machine, it would generally be left behind when coming to close quarters. If worn on the belt it would generally get through the sjokes of the wheels. I think most practical soldiers will agree that, as far as an infantry officer gocs, it is an obsolete weapon ; simplicity is its only virtue; but as it generally secms to break directly it is really tried, personally, I should always prefer to have two pistols. I say two, in case of one going wrong, as, unfortunately, revolvers are apt to do. A really simple repeating pistol is much necded.

Dress and Equipment of the Cyclist. - Though a big head-dress catches the wind, a belt is uncomfortable when leaning forward, and ammunition boots are not suited to pedals, otherwise there seems no reason why a cyclist should not be dressed as any other soldier; except for the reason that nowadays all smart and artistic cfeet secms to be discarded as much as possible. Breeches and stockings are all very well, but one can picture the cyclist who, after two or three months of campaigning, has worn them out and gladly aclopted a pair of grey socks out of storc, and cut short a pair of "tartan" trouscrs.

Then boots or several pairs of strong shoes must be taken. A machine is always liable to break down, and the man may have some long marches to perform on foot. The French carry two pairs of shoes on the machinc.

A good deal might be said as to which articles of equipment should be attached to the man and which to the cycle. For comfort (which is nearly synonymous with efficiency), the less the man has on himself the better. But yet, as he may have to fight away from his machine, he should have a good supply of ammunition on him. As he may have at any moment to change machines with another man, he oughl, also, to keep his own personal articles on himsclf. But of course much will depend on the particular service in which he is to be employed. As a machine may at any mument have to be abandoned, it is essential that the kit carried on it should be readily detachable.

I think everyone is more or less in agreement as to the efficiency of a bicycle for employment in war, but it is most necessary to bear in inind that that efficiency is dependent on the exact form of machine used, and if we are not careful to select a suitable build, formed of the most suitable materials, and fitted with most suitable accessories, we may discover, too late, that the efficiency was not so great as we had expected.

Before closing, I should like to add a word of thanks to Colonel Savile, to Major Liles (of the Cyclist Volunteers), to Captain 
Swindley (also of the Cyclists'), and to many other authorities, who have been so kind as to give me valuable assistance in the compilation of this paper.

Major W. ANstruther-Thomson (Royal Horse Guards): - Thereatreone or two small points I should like to mention. I happened to be at the French manceuves last September. There were two army corps there and two cavalry divisions, and Captain Gérard was there with his cyclist corps, and he did a lot of very rrood work. It surprised me to see how he was able to keep up with cavalry and to come both in aid of cavalry and against cavalry. I had hitherto thought that the bicycle could not hold its own with cavalry in any way whatever, but certainly in France at those manouvres I found that in many cases I was wrong. The Girard cycle is a folding cycle, and the men are able to fold and sling it in about three-quarters of a minute and carry it away on their shoulders (they did not carry a pack). They conld thus go across country and over fences; in fact, they could go anywhere-and they came in, on several occasions, in the most remarkable manner. I do not for a noment hold that the cycle can ever take the place of cavalry or mounted infuntry. I think it is a great mistake to compare them in that light. But I do think that the three forces-cavalry, mounted infantry, and crelists-are most valuable auxiliaries to each other; and if we rui on those lines we shall do vers: good work. I should like to quote a French newspaper, the Revue de Corcle Militaire, as follows : - Cycles have conclusively established their military value; and cavalry, which originally looked down on the whelmen, are now their best friends, it being found that the two forces are the complement of each other." That is the gist of the whole question, to my mind, as far as regards cavalry and mounted infautry. From my owa experience as a squadron commander, I have found eycles of the greatest use. General Luck allowed us to use cycles on reconnaissance if we could get, them (we had of course to provide the cycles ourselves)-I always had as many as I could get, generally three or four-and I found them most useful, saving both time and horseflesh. Captain Gérard, I may mention, at the French manœuvres was not mounted on a cycle, but rode a cob, and did a lot of reconnoitring for his little force; be recognised the fact that to get the full value of cyclists, scouts on horseback are essential, just as they are with nachine guns. I am convinced that the cjulists owed much of their success to Captain Gérard's wisdom in riding a cob instead of a cycle. It often occurred that the horse could gallop over ground which checked the cycle, and sometimes positions could be selected and ground recomoitred before the cyclist scouts carrying their cycles could possibly get there. 'This saved time, and time wins battles. A few horsemen attached to a cycle corps should prove as useful to them as cycles are to cavalry, only of course in a. different way: There is one point upon which I differ from the lecturer, and that is where he speaks of shock action. I do not think that really shock action comes into the question of cyclists at all. Nur do $I$ think that a revolver fired by a cyclist in motion would do much execution to the enemy, and I do not think that a scout armed with a revolver would have that confidence which is necessary to push his way into an enemy's country. What you want in your scout is confidence, and I think he would do far better with a carbine. By all means give him a revolver as well, if you like; but, personally, I do not look on a cyclist armed with a revolver alone as a very terrible antagonist. Cavalry would not be stopped by revolvers fired by cyclists. The French wear, as you probably know, puttees, instead of gaiters and shoes. These puttees seemed to be very serviccable, and did not appear to hamper them in any way. The men were armed with cavalry carbines and short bayonets. They carried the carbines slung over their shoulders as the cavalry do in France, and when marching with the cycle on their backs they carry the carbine at the trail. Their baggage was carried by a cavalry wagon with the cavalry baggage. That is an important point. If you are going to carry your cycle on your back, you cannot carry a knapsack 
there as well. The Austrians are experimenting with automobiles, and $I$ believe the reports are very favourable. They hope to do a lot of their transpor work now with these motor cars, and the French, I fancy, are going to follow suit. They might possibly be used where good roads prevail to carry the cyclists' baggage. Machine guns on cycles have vast possibilities if you can only carry enough ammunition. There is no reason why you should not do wonders with the machinegun on a couple of cycles fitted with either Lord Dundonald's coupling or some other. I should like to ask whether the 25-1b. Maxim includes a tripod. To sum up, I think that military cyclists, Horked as Captain Gérard worked them, would be of the greatest service in war; but if you arm your men with a revolver only, and mount him on a cycle that cannot fuld wp or be carried across country and over fences, you rob him of half his value.'

Colonel A. R. S.wvile (late Royal Irish Regiment):-Although, Sir, as you know, I am not now actively connected with military cycling, I am very pleased to be able to say a few words about it to-dlay, even if it be only to congratulate Captain Baden-Powell on the excellent lecture he has given us, and to congratulate ourselves on having heard it. I am afraid I am hardly up-to-date now on military cycling. It particularly interests me to hear what new things have been done since I resigned my commission in the Cyclist Corps. I am also interested to hear the list of objects for which cyclists might be employed, and to learn whether any new ones have been invented since we hegan about twelve years ago. I think most of them appear to be very much the samc, and that, of course, is distinctly pleasing to all of us who had a share in the work at the commencement. I take it that if they are now included in the list, cyclists have shown that they can do them, and do them efficiently. There is one new one, No. 6. I think Captain Baden-Powell is a very bold man to come before an assembly of cyclists and suggest they should be used as transport animals. I do not know whether it is a mode of employment which would be propular or would attract many recruits. As our chief characteristic is speed, it does seem hard to make us haggage carriers. I was very much pleased and rather amused to see amongst the list of duties one I suggested nyself long ago-namely, escorting artillery. Some of you may perhaps remember how exceedingly heavily I was jumped upon at the time by a critic, who said it was a perfectly ludicrous thing to suggest that cyclists should escort artillery. I think the laugh is more on my side now, because in the Cavalry Drill-Book it distinctly says that mounted infantry are to be used to escort horse artillery. Possibly it may be argued that that does not apply to cyclists, but oily refers to infantry mounted on horses. But we have the opinion of the Commander-in-Chief that you cannot dissociate cyclists from mounted infantry, and I fully agree with him. Then, with regard to the folding bicycle, I have never personally favoured it, and the chief things I wished. to hear to-day were the arguments in favour of it. I think Captain Baden-Powell has made out an excellent case in favour of the folding bicycle, so far as a case can be made out. We shall probably hear this afternoon the opinion of officers who are practically engaged in military cycling, who will tell us whether they have found the folding bicycle of use on certain occasions, and if so, on what occasions. I do not think I have ever been across country with military cyclists when to have folded the bicycles and put them on our backs would have got us on faster or easier. The bicycle has got to carry the man, not the man the bicycle. I really think that over grass, stubble, or anything like that, one uould ride the bicycle as

So useful were Captain Gérard's cyclists found at the French manceuvres, that several of the generals formed their cyclist messengers into sections, and placing then under officers on cycles used them in the same way as Captain Gerard's corps. It was thus possible to compare the work done by troops mounted on the ordinary cycle which had to follow the roads, with those on the folding cycle that could be taken across country. I Ion't think that anyone who has seen the two together would hesitate in declaring for the folding cycle. The entire mobility proved invaluable.-W. A.-T. 
has been pointed out; but on rough ground I think pushing it would be better than carrying it. I cannot conceive any hill so steep that one would rather carry a bicycle up than wheel it. It oftens helps a man to stand by his bicycle and lean on il, and the steeper the hill the more disinclined I should be to carry the machine. As regards the special machine, my opinion is, that any really good bicycle is fit for military purposes. I do not see that very great weight is required. It is one of the chief features of modern cycle construction that very great strength can be obtained without great weight. Weight and strength at the present time are not synonymous in eycle construction. You cąn have a fairly light bicycle, and yet one strong enough for military. purposes. It is very pleasant for everyone connected with military cycling to know that the movement is progressing, that there are more military cyclists every year, and that it is getting more popular. The last figures I have show a strength of 3,411 . That, I think, is very satisfactory, particularly when we consider that the men are well equipped, well trained, good shots, and efficient cyclists. The figure I quote is an old one, dating from October 31st, 1897. The Volunteer returns for last year, I think, are not yet out. I should have liked any lecture on military cycling to include a suggestion to the authorities to give more support to the Volunteers-to help them a little with the expense of providing machiues. I believe the Ytomanry soldier receives something for his horse, or at any rate that his horse is fed for him when he is out. The Volumteer cyclist might be allowed oil for his machine at the rate of a shilling a day whenever he is on military duty. Major Liles and others will probably tell us what a tax it is on the men of the corps to keep their nuchines in military order and ready to turn out. Mancuvres take a good deal of value out of bicycles, and I think a portion of the expense ought to be borne by the country.

Lieut.-Colonel E. Guxrer (late East Lancashire Regiment):-I think, Sir, we are very much indebted to the lecturer for the very able lecture he has given to us, and for showing us that most ingeniously contrived detachable bicycle. I think any military bicycic must be a portable one. - Personally, I have a very painful recollection during the late mancuvres at Salisbury of pushing my bicycle up the steep hillsides there, and, nolwithstanding what the - last speaker has said, I think I would rather have had sone kind of portable bicycle. We have not, I suppose, time to go into the details of the lecturer's contrivance, but I have no doubt it offers a great many advantages. However, the fact of the portable bicycle being adopted in France and Germany speaks for itself. I should like to ask the lecturer whether, in addition to those he mentioned, he knows the "Styria" bicycle, which is used in Austria, and the "Adler" portable bicycle, made by the "Adler" Company', a well-known bicycle factory in Frankfort. I have scen it myself, and it is a very strong machine, jointed with a simple bolt. Its weight, $i$ think, is not very great, about 32 or 33 lbs. As Colonel Savile said, we need not, I think, have such very heavy machines as the lecturer mentioned. W' might get one of from 30 to $35 \mathrm{lbs}$. weight, which would answer all our requirements. The lecturer said that a battalion of cyclists could be despatched very rapidly in case of invasion, and that it would take only five or sis hours to reach the coast. I think that with the experience our staff has had in sending down troops, they would be more likely to send them down by rail in two and a half hours. Of course a large number of cyclists might be sent on emergency-for instance, if the railway were destroyed. A rapid raid on a railway might destroy it, even though there was not much time to break up the roads, and then to send the troops on cycles would be uscful. But, as regards a dozen battalions, where are they to be got? I am, of course, speaking of the Line, and not of the admirable Voluntecr Cyclist Corps which we have. There are not many Line troops who are able to ride cycles, and I venture to suggrest it would be an excellent thing if every infentry battalion was allowed to hate three cycles in each company. They would be useful for all kinds of things in camps, as. messengers, etc., and with the aid of these three cycles a section of twenty-four

VOL'. XLIII. 
men in each infantry battalion might be formed, and by means of those cycles by degrees almost the whole of the men might be trained regimentally to rite cycles; thus on emergency they would be of great use. I quite agree that the cycle might be of value for transport purposes, and I dare say the lecturer knows as well as I do that something of the kind was designed before the days of cycles by the late Colonel Heyland. He designed a most ingenious carrier, the details of which will be found in the library of this Institution. It was used practically and spoken very highly of in India, and I have no doubt something of the kind might be adopted. With regard to tyres, of course that is most important. I do not think myself that you can do with the pneumatic tyre. I think you must have a solid tyre for military purposes, because the pneumatic tyre, as has been said, is so liable to puncture, and could be easily cut and damaged by cavalry. Solid iyres are not so heavy as they used to be, and, as the lecturer pointed out, they have been improved. With regard to the armament, the point bas been brought out very well by the offier who spoke first in the discussion. I think the wenpon should be a carbine, and that we should not rely on the revolver; a carbine would give the men much more confidence. The difficulty of getting across broken ground liats been alluded to as the reason for adopting portable cycles, but I think there are many instances where portable cycles would be almost a necessity. Take the case of cavalry suddenly charging down on a road with high banks. Notwilhstanding the long tims that it has been saijl is neessary to pack the machine, there is no donbt well-constructed portable machines could rapidly be put on the men's shouklers; and they could climb up the banks with them, where the cavalry could not easily get at then. It is all very well to say cyclists can always resist cavalry ; but if they had pneumatic tyres, at all events the tyres could be easily slashed or punctured with swords or lances. $\dot{C}_{y}$ clists can hardly hold their own unless they can take advantage of broken ground-it depends upon the ground a good deal; but on the whole, I think, portable cycles will be found to be the best for military work.

The Cinsirmax (Major-General H. H. D. Stracey) :-I do not know, Colonel Savile, whether you would like to add to the interesting remarks you have made by griving us the benefit of your advice on the most desirable tyres to use-on the gencral principle of whether solid or pneumatic tyres should be used.

Colonel A R. S.Ivile (late Royal Irish Regiment):-I am atraid, Șir, I am not in a position to do that. Whenever people speak about tyres they always say they are not interested in them. The one tyre which I think is not a bad one for military purposes is the one I am distinctly interested in; and that is the reason, Sir, I hardly like to name it, if you will excuse me.

Major C. E. L.ILes (Commandant Volunteer Cyclist Corps) :-I should, Sir, like to support Colonel Savile's remarks complimenting Captain Baden-Powell on the excellent paper he has read this afternoun. It has been the most comprehensive paper I have yet met in connection with military cycling, and I think all here are very much indebted to him for the trouble he has taken to prepare it. I have seen a good many different types of folding cycles, but I do not know whether I have met those which Colonel Gunter mentioned. As we have already heard, there are several obizctions to folding cycles. They are likely to get out of orcler, and if you are going to use portable cycles, from all the machines I have seen there are none so near perfection as Captain Baden-Powell's invention. His cycle is quite simple, it adds nothing to the weight, and it fulfils every requisite that I can suggest or think of. Colonel Savile made some remark about never finding a place where a portable cycle would be of any use. I agree with him to a certain extent, but I have seen some places I should not like to push a machine up myself. I have reminiscences of sundry Scotch moors where pushing a machine would be out of the question. If it had been a portable one I should also have left it at the foot of the hill and gone on, trusting at some future time to find it again. I 
consider that a country where cycles are of no use at all and where you would not employ them, and you would use mounted infantry or cavalry for any work that had to be done in such at country. Is far as my limited experience goes of mancuvres in the South of England, I have not yet come across a place where portable cycles wosuld be a necessity. Colonel Gunter mentioned one possibility I have had experience of it - a road where high banks and hedges exist. Oin such a roat the cavalry when attacking would have to come up in solid formation with a very small front, and they would not be able to face the rifle fire. In a road with high banks you could only bring up cavalry ten or twejve abreast, and a few horses going down would check those behind them. As far as the armament goes, I think with several of the speakers that the carbine would be better than the long rife. I am taking it from Culonel Lockyer's remarks that the effeacy of the carbine up to 1,400 yards is practically the same as the rifle, and I do not think, at all events at the present time, we are likely to want to do much shooting beyond that range. The carbine would certainly be much easier to handle and less weighty to carry. There are two little details on which I rather join issue with the lecturer. First of all, I am not a supporter of his idea of shock action. I think that is rather remote. Another thing that I do look upon is that on a machine for rough wear a gear case is a necessity. I remember a competition held at Blackwatter some three or four years ago, over at sandy road on at wet day. The only team able to finish in anything like decent time was one with machincs fitted with gear cases. All the other machines catme to grief through having naked chains; the chatins got full of gril and snapped. I should not like to say off-hand how many broken chains there were, but I should siay there were over twenty on that day.

The Clinrmax :-1 remember it.

Major LiLes :-I think you were there, Sir. Team after teim came in reporting that they had given up, owing to chains breaking. I think that was the greatest object-lesson in favour of gear cases I have ever seen. $A$ gear case need not be heavy. You do not want metal gear cases, as long as you keep the grit and sand off the chains. I have found from experience that a leather gear case answers all the purposes, and I have used leather ones for five or six years, and during that time I have ridden something like 20,000 miles. Therefore, $I$ am speaking from a fair amount of experience. With regard to tyres, I quite think there should be some ferm of cushion tyre. The solid tyre is tuo heavy, but there might be sone kind of cushion tyre which would be useful. There- ave been various kinds put on the market, but I do not wish to refer to any by name as it is putting too much of a premium on advertisement. Like Colonel Savile, I am rather diffident about mentioning any tyre by name. I remember that once I did make a remark that I thought a certain tyre would be of use, and I had the pleasure of secing my opinion handed round on handbills at the Stanley Show. I do not think there is any other point I need refer to, except with regard to a grant from Government for military cyclists. As far as the Volunteers are concerned we do not get any increased grant for the wear and tear of cycles. The battalions have to do what they can for the men in that way. In fact, I nuke it a rule in my corps, that the battalion pays for all damage that occurs during manoiduvres or drills, provided the machines are satisfactory and are passed by a Board consisting of one officer, one non-commissioned officer, and a competent repairer. The two conditions I make is that the machines shall be fitted with an efficient brake and wilh mud-guards. Mud-guards on active service, I agree, would be of no use at all. They are only in the way and add weight, and more or less give trouble; but for peace work, where one wants one's uniform to look decent, a pretty good mud-guard is a necessity. The valise will hardly serve the purpose of keeping the mud off. I should very much like to sec a grant made by the authorities for cyclists. It woukd enable the officers commanding corps to exact that all machines should be of one particular 
pattern. As they can offer no inducement for men to do that, you can hardly exject them to be so patriotic as to get machines which would be suitable for military purposes, but hardly so light or fast as they would like for their private requirements. In conclusion, I thank Captain Baden-Powell for his most interesting lecture.

Major B. St. J. B.ARTER (Lincolnshire Regiment) :-After the very interesting and cxhaustive lecture which Captain Baden-Powell has given, there is very little left to be said, but I just want to give my experience on one occasion when I wats engaged in a cycling reconnaissance. It was in the neighbourhood of Woolwich, and about thirty officers of the garrison, who volunteered, reconnoitred about 200 square miles of country, a sector comprised within the boundaries of the Thames, the Medway, and the London and Brighton line. We started about ten in the morning, and all the reports were rendered at headquarters about six in the evening, and the whole of that country had been thoroughly reconnoitred in the time. I think it could not probably have been done as thoroughly, or as fast, by cavalry. On another day we had a ride of officers, non-commissioned officers, and men of the garrison, who voluntecred just simply for experimental purposes, to find out at what pace we could ride in formation for a couple of hours. Of course we were lightly equipped, in fact no arms, or ammunition, or kits were carried, and we covered about 20 miles in the two hours. It therefore evidently does not require very much training. The formations were well kept, and the distances also were well preserved. I mas mention that the reconnaissance work at the Staff College is very much done nowadays on bicycles, and an officer is able to do infinitely more work now on his bicycle than he ever did before. Ile is able to go over all sorts of ground. I have done a grood deal of work of that sort myself, and $I$ agree with Colonel Savile in that respect, that I have never yet come across ground where I could not wheel my bicycle. Over most ground I could riste it. I think that the carbine is the proper arm to give bicyclists. The long rifle is a little inconvenient and not tery handy, and you want something with which you can take a better aim than the pistol or revolver. Cyclist infantry, as the lecturer said, should be merely infantry carried on cycles, and I think shock action does not come into play at all. The question of the gear case is a very important one, and I certainly think that a gear case should be upon a bicyele. It is the crux of the whole thing. If you get your cliain cither muddy or rery lusty the bicycle will not run smoothly and the chain is apt to snap. I am sure we are all excecdingly grateful to Captain Baden. Powell for his excellent lecture.

Major C. J. Fox (3rd 13n. Middlesex Regiment) :-We must all feel very much indebted to Captain Baden-Powell for his excellent lecture. I should have hesitated to obtrude my opinions on the meeting except for the fact that I was instrumental in raising the first force of military cyclists, and being present I think it well to say a few words, because anyone having any sort of knowledge on a question like this should, for the public benefit, state what he feels and knows. First of all, one point which strucls me was the very small number of Volunterer cyclists mentioned by Colonel Savile. At the present time there are only some 3,000 ; there ought to be 30,000 , and might be. As I urged on the authorities some years before you, Sir, took the initiative, the cyclists should be got at through their cycles, and not by means of voluntecring. With regard to the shock action suggested, anyone who knows anything much about cycling on the road, or meeling with cavalry or infantry, will see that that could not possibly be of any use. Not once in a thousand times coult it avail the cyclist infantry anything at all, and it would always lead to disister. It is most important that there should be means of readily disabling cycles, becanse if they are simply to catry infantry (and I hold that is their proper function), if they have to be abandoned and fall into the enemy's hand, they will possibly get into the liands of other cyclists in the ranks of the foa, and could be made use of against us; whereas a small readily released handle-bar or saddle-pillar would render them quite useless, and when they were 
recovered they would be again available. With regard to borses facing cyclists, we had during the manceures, of which you, Sir, hat command an instance of what might be expected. Ilorses will not, unless they are accustomed to it, face cyclists. 1 few cyclists can block a rond with their machines and make it, for a time at all events, impassable to cavalry, and meanwhile the eyclists can line the road and bring about a great disaster, by throwing the enemy's cavalry into disorder. I am sorry to differ from the lecturer, but really as an old cyclist, a present cyclist, and one taking a very great interest in cycling, I shoukd be very sorry to see the cyclist infantry man converted into a sort of Christmas-tree. It is bad enough to see the average infantryman to-day, who is sufficiently hampered with impedimenta. I think you would dishearten the men and lower the prestige of the eyclist infantry generally if the men were made into baggrage carricrs. I think they should be trested entirely as light infantry, and in that way they could invariably be made of very great service to any general officer wishing to employ a force at some distance, with a view to securing a position. Iith regard to the officer's sword, I quite agree with the lecturer that the infantry sword on the bicycle is not reguired. If any weapon of that kind is to be taken, a good naval cutlass is about the best thing, and that won't fail you. I was very glad to hear Major Anstruther-Thomson say that it was very undesirable indeed that eyelist infantry should be compared with cavalry. Their functions are entirely different, and unthing has done more to retard the cyclist movement than the early jealousy of the cavalry towards the cyclists, who are, and always must be, mounted infantry. In the old days, in fact, it was considered discreditable to be a military cyclist at all or to have anything to do with it. With regard to the folding bicycle, I am sorry to siy as an experienced cyclist that I quite disapprove of folding machines or military purposes. It may do very well for the purposes of drill to put a bicycle together in ten or fifteen seconds, but it will not be so easy under fire; and besides that, you have a double surface of tyre, if you are using the pneumatic tyre, presented to the eneny's bullets instead of a single surface. I certainly agree with Major Liles that if you are to have a folding bicycle the type shown by Captain Baden-Powell is the best we have yet scen. The only thing I would suggest is that the men using such machines should have a very good pad on the left shoulder to talie the strain from the collar-bone. I dare say most of us noticed that when the guardsman knelt down with the machine here in order to rest it on the ground the machine slowed a tendency to run forward and backward, and I therefore think some arrangement should be male for putting a pin through to prevent that, so that the wheel when on the ground should be perfectly' stendy. Without such an irrangement, steady fire is impossible.

Captain BADEN-PoweLt, in reply; snid :-First of all as regards the Maxim gun which Major Anstruther-Thomson spoke about, I an sorry to say I cannot give him the desired information. I wrote to Mr. Maxim to ask what was the weight of his lightest gun, because some time ago he showed me a new gun which he had just produced, which was very small and light. He wrote back saying:-" we have never yet mounted a gun on a bicycle, but we have on a tricjele. The guns without water-jackets weigh 25 lbs. each ; with the water-jacket 32 lbs. They can be carried on a bicycle." That is all the details he gives. I should imagine the bicycle itself would form if not a sufficient tripod, at all events assist in forming it.

Major Axstrutner-Thomsox:-The Americans have got a machine gun of thet sort mounted on a bicycle.

Captain BaDEN-Powell :-Several of the speakers have taken exception to the idea of using the bicycle for transport purposes, but they seem to miss the point. I endeavoured to show that this would only be done in cases of emergency. I mentioned several cases in which it might be most desirable to use them for such purposes. Then, with regard to wheeling uphill,-of course if a hill is very stecp 
it is diffieult to get up it, whether you are wheeling your machine or carrying it; but I am inclined to think there are a good many hills you could not wheel your machine up; at any rate, you would have to seize it by both handle-bars and push away very hard. It is verj difficult to wheel a machine up a steep hill, especially when heavily londed. Although carrying it would not be much easier, I think my'self it would be somewhat easier. As to those foreign bicycles mentioned by Colonel Gunter, the "Styria" and the "Adler," I have only seen reference to them in the papers, and I have been trying to find out what they are. I wrote to Gerinany for details but was unable to procure them.

Colonel Guster :-You will find them described in a German paper of which I will give you the details.

Captain Baden-Powel. :-Thank you. As regards the weight, one of the speakers has said $40 \mathrm{lbs}$. might be rather heavy. In that particular respect I got the expert opinion of some leading makers-Mr. Pugh, of the Rudge-Whitworth Co., and Mr. Starley, of the Rover Co., and others-and they considered the average weight for a thoroughly strong machine ought to be pretty well 40 lbs. As regards the diespatch of forces, say from London down to the South Coast by bicycles instead of by rail, although it is true, in peace-time, when plenty of preparation has been made, you may be able to despatch a force in a very few hours by railway, the chances are that on service, when you have no time to make preparations and suddenly find you have to despatch a force, the lines may be so blocked and unprequared that I do not think troops going by rail would get there in much less time than by bicycle. Then, in addition to that, some troops could be sent by rail, while others were being sent down by cycles. As regards shock action, I am afraid I have been taken rather too seriously. It is the same as regards the transport. I was rather referring to certain particular occasions when it might come useful. I cannot help thinking, as I said before, that the occasion night come-I do not say it wonld be usual-when, where you have good open ground, a force of cyclists could make a dash towards the enemy and then dismount and charge. Though I suppose nobody has had experience of it, certainly I think that in going along a road and finding your way harred by a small force of the eneny, you might ride straight up to them. Although not quite the same thing as shock action, the moral effect on the cnemy of seeing the cyclists coming rapitly down upon them might be sufficient to cause them to turn and run. As regards the revolver, although I should not care to be any'where near whilst men were practising firing with it from a moving bicycle, still I do not sce why they should not be able to make fairly good practice with the revolver'; it certainly' would lave a certain amount of noral effect. If a cyclist was coning along a road firing a revolver right and left you would probably get out of his way. As to the machines being readily disabled, of course that is one of the points about this particular bicycle of mine. It is merely a malter of turning the screw to take the handle straight off and you can take it away with you, as it is very light and easy to carry. As soon as you get back to your machine you can put it on again. I think that is really all I need say. There are a good many machines here, and I shall be very glad to show them to anyone who requires nore details. The French Gerard machine which I have here is unfortunately a very ola ', the only one I have been able to get hold of in England; but it shows the o neral mechanism. Sergeant Rule of the Cyclist Volunteers, and Mr. Thorn of the London Scottish, have brought their bicycles here with the full Volunteer equipnent on them and it is very interesting to sec how the equipment is attached, and how the rifle inay be carried. I thank you all for your attention.

The Citurnus:-I would ask you all, gentlemen, to second me in a vole of thanks to Captain Baden-Powell for the most interesting lecture we have received from him. 